University of California

Division of Agriculture and Natural Resources

http://anrcatalog.ucdavis.edu

\title{
Citrus Leafminer and Citrus Peelminer
}

ELIZABETH E. GRAFTON-CARDWELL, University of California, Riverside, and UC Kearney Agricultural Center; KRIS E. GODFREY, California Department of Food and Agriculture, Sacramento; DAVID H. HEADRICK, Cal Poly San Luis Obispo; PEGGY A. MAUK, UC Cooperative Extension, Riverside; JORGE E. PEÑA, University of Florida, Homestead

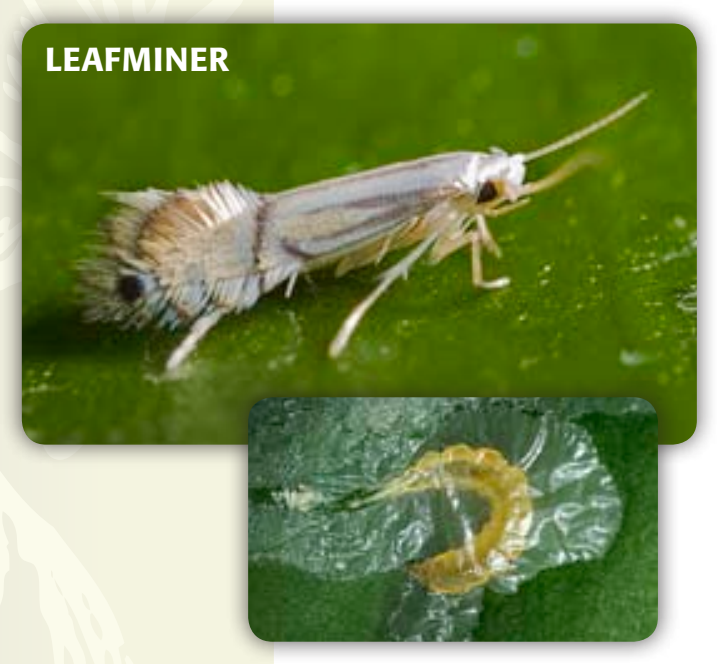

Two closely related species of moths can cause problems for California citrus growers: citrus leafminer (Phyllocnistis citrella Stainton) and citrus peelminer (Marmara gulosa Guillén and Davis) (Lepidoptera: Gracillariidae). Damage by both pest species is caused by the larval stage of a 2-mm sized moth (microlepidopteran). Knowing which moth is present within a grove is important because their life cycles, the damage they cause, and therefore their management programs differ.

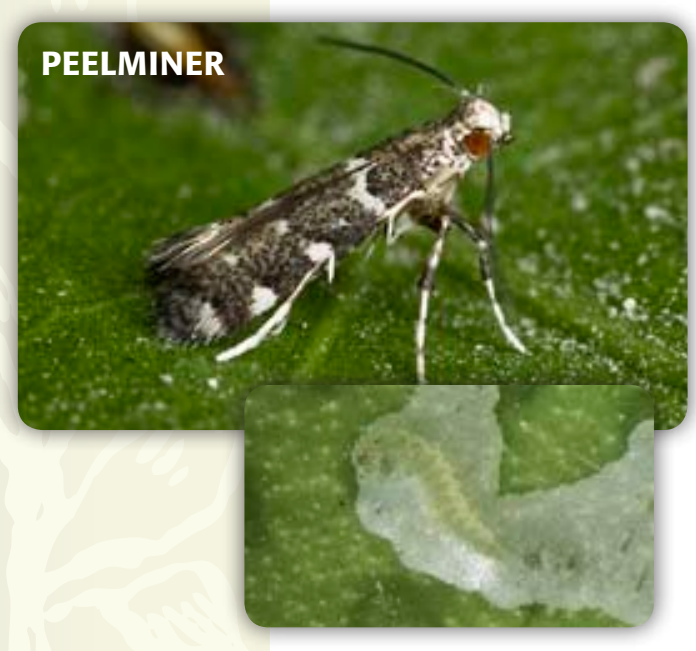

\section{CITRUS LEAFMINER}

The citrus leafminer (CLM) is native to Asia and can be found throughout Asia, Taiwan, southern Japan, the Philippines, Indonesia, and New Guinea, as well as Australia, South Africa, parts of West and East Africa, the Mediterranean area of Europe, and from Saudi Arabia to India (Heppner 1995). CLM can also be found throughout the Caribbean Islands, Central America, Mexico, and South America (Ruíz and Blanco 1994; Bermudez et al. 2004; Hoy and Jessey 2004). In the United States, CLM was first found in southern Florida in 1993 (Heppner 1993). Since that time it has spread throughout the citrus-growing regions of Florida and into Louisiana and Texas (Johnson et al. 1998; Legaspi et al. 1999). In 2000, CLM was first discovered in Imperial County, California; it is widely assumed that it migrated from Mexico. Since then, it has slowly spread westward and northward into California citrus-producing areas. 
CLM larvae feed by creating shallow tunnels, referred to as mines, in young leaves of citrus trees. It is most commonly found on citrus (oranges, mandarins, lemons, limes, grapefruit, and other varieties) and

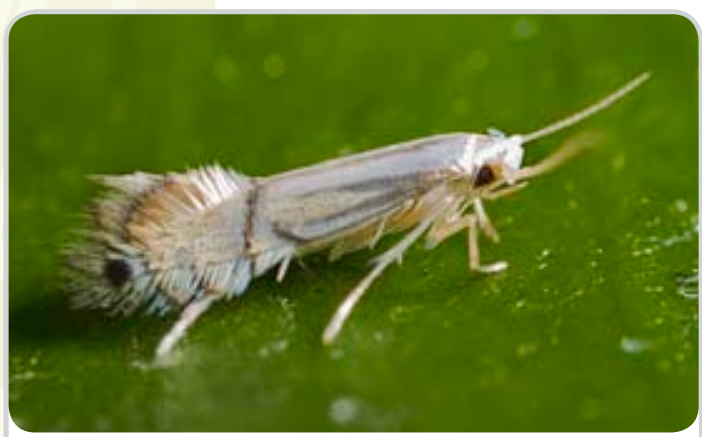

Figure 1. CLM adult moth. Photo: J. K. Clark. closely related plants such as kumquat and calamondin. Adult CLM is a very small, light-colored moth, less than $2 \mathrm{~mm}$ in length (fig. 1). It has silvery and white iridescent forewings with brown and

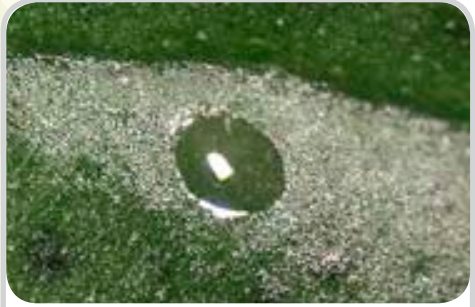

Figure 2. CLM egg deposited on a leaf. Photo: E. GraftonCardwell.

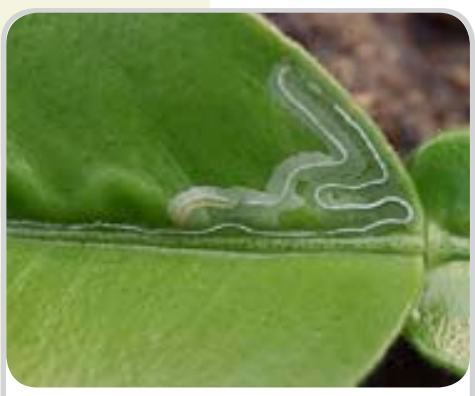

Figure 3. Young CLM larva. Photo: E. Grafton-Cardwell.

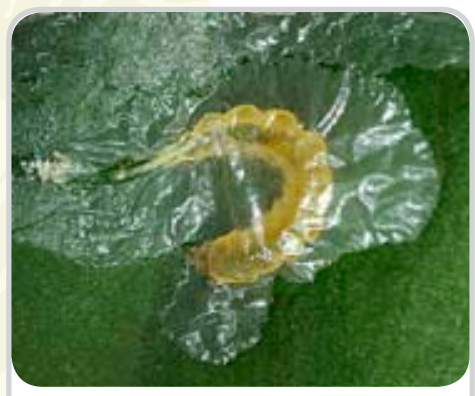

Figure 4. Close-up of CLM larva with frass trail in the mine. Photo: E. Grafton-Cardwell. on the internal parts of the leaf by shearing the plant tissue, resulting in a serpentine mine (fig. 3). A larva leaves a frass (feces) trail as it feeds and develops, observed as a thin light or dark line, inside the mine (fig. 4). This visual characteristic is used to help identify the pest. A citrus leaf can support more than one larva, and commonly two to three larvae can be found on both the upper and lower surfaces of the leaf. As many as nine mines per leaf have been reported in Florida (Murai 1974; Heppner 1993). Larvae complete four instars (three feeding instars and one instar as a nonfeeding prepupa). The length of the larval stage has been found to range from 10 to 19 days depending on temperature (Ba-Angood 1978).

The larva emerges from its mine and rolls the edge of the leaf over, causing a slight curling of the leaf margin (fig. 5). Inside that curled leaf edge a light-colored prepupa and then a dark brown pupa forms (fig. 6). The pupal stage lasts from 8 to 20 days depending on temperature (Ba-Angood 1978). Adults emerge in the morning hours, and mating occurs in the evening hours.

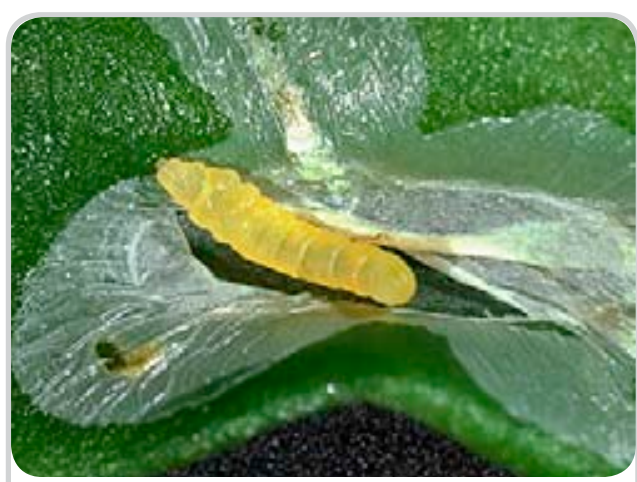

Figure 5. CLM prepupa in the curled edge of a citrus leaf. Photo: E. Grafton-Cardwell.

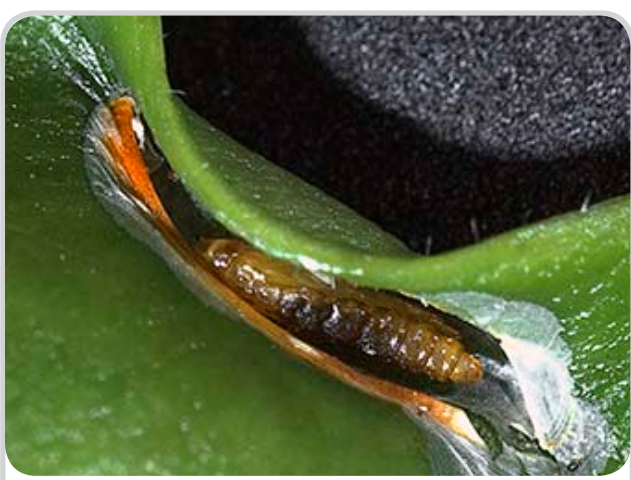

Figure 6. CLM pupa in the curled edge of a citrus leaf. Photo: E. Grafton-Cardwell. 


\section{CLM Seasonal Phenology}

The phenology of CLM has been studied extensively throughout the world. In Asia, CLM completes five to six generations per year (Clausen 1931). In Australia, CLM is found throughout the year but in greatest abundance during periods of new flush in citrus (Wilson 1991). In Florida and Texas, infestations of leaves are lowest in the winter and early spring, increasing significantly through the late spring, summer, and early fall (Peña et al. 1996; Legaspi et al. 1999). During the colder months of the year, CLM does not enter diapause, but instead development slows and adults live longer (Lim and Hoy 2006). Although CLM has only recently arrived in California, observations in the interior southern, coastal, and desert regions indicate that it is most active during summer and fall.

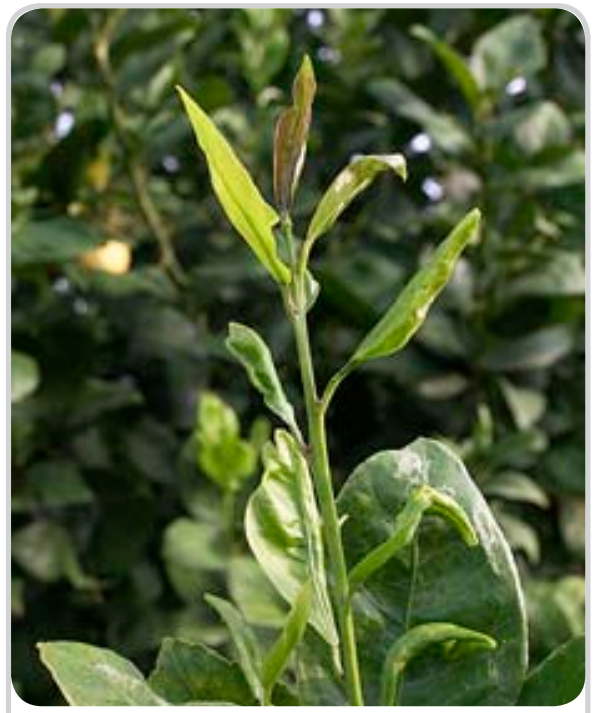

Figure 7. CLM leaf curling damage of lemon flush. Photo: E. Grafton-Cardwell.

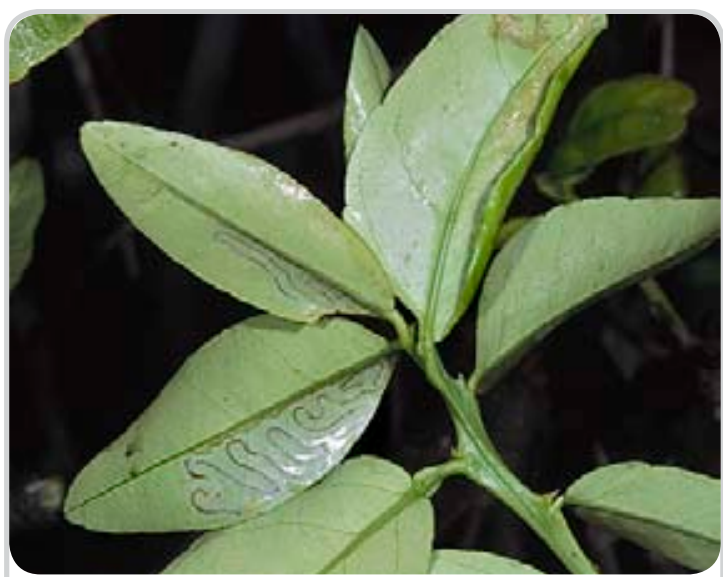

Figure 8. CLM damage to the underside of flush. Photo: UC IPM.

\section{CLM Leaf Damage}

The larvae mine inside the lower or upper surface of newly expanding leaves (fig. 7), causing them to curl and look distorted. The larvae will not cross their own mine or the mine of another larva (fig. 8). The larvae continue to mine as the leaf fully expands (fig. 9). After the CLM emerges, the damage to the leaf caused by mining activity remains (fig. 10). Older leaves that have hardened off are not susceptible unless extremely high populations are present.

Mining damage can cause a retardation of plant growth of young trees and nursery stock. Studies in Florida have shown that significant stunting can occur if trees are not protected from CLM with insecticides from the time of planting until they are about 4 years of age (Rogers and Stansly 2007). Yield losses generally do not occur in mature citrus trees. Mining of the fruit rind by CLM may occur, although it is rare.

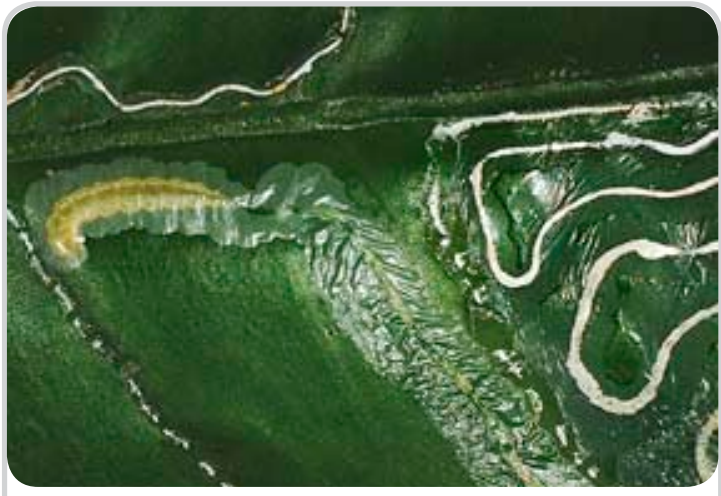

Figure 9. Serpentine mine of CLM with frass trail. Photo: E. Grafton-Cardwell.

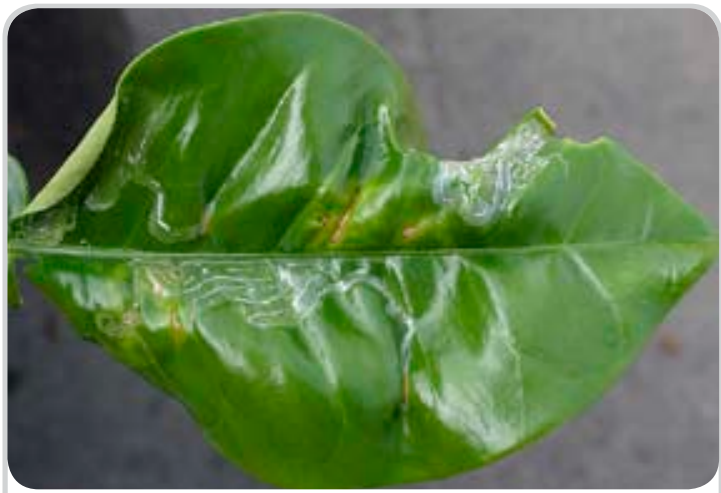

Figure 10. Twisting and curling of leaves due to CLM mining. Photo: E. Grafton-Cardwell. 
In Florida, CLM damage exacerbates the citrus bacterial canker situation. Citrus bacterial canker is a serious disease of citrus that initially causes lesions on the leaves, stems, and fruit. If the disease is allowed to progress, defoliation, severely blemished fruit, premature fruit drop, twig dieback, and tree decline will occur (Schubert and Sun 2003). Although CLM does not vector bacterial canker, feeding by larvae provides an opening to the mesophyll of the leaf for citrus canker, and a larva may carry the bacteria throughout the mine, increasing the amount of canker inoculum produced in a leaf (Gottwald et al. 2002; Belasque et al. 2005). Citrus canker is thought to be native to Southeast Asia or India and has spread throughout much of the citrus-growing regions of the world (Schubert and Sun 2003). It has been successfully eradicated from South Africa, Australia, the Fiji Islands, Mozambique, and New Zealand. The citrus canker eradication program in southern Florida was discontinued because of legal issues. In California, citrus nursery plants are routinely inspected for evidence of citrus canker, and a statewide annual survey for citrus canker is conducted in commercial citrus to prevent this disease from establishing. More information about citrus bacterial canker is available in a free publication entitled Citrus Bacterial Canker Disease and Huanglongbing (Citrus Greening) (Polek et al. 2007, http://anrcatalog.ucdavis.edu/pdf/8218.pdf).

\section{CLM Biological Control}

Worldwide, biological control has provided the most effective management of CLM. Native natural enemies in southern Florida are responsible for approximately fifty percent of the mortality of CLM larvae and pupae (Amalin et al. 2002). In Florida, Texas, and

Louisiana, 16 species of parasitoids (11 genera in 3 families) are associated with

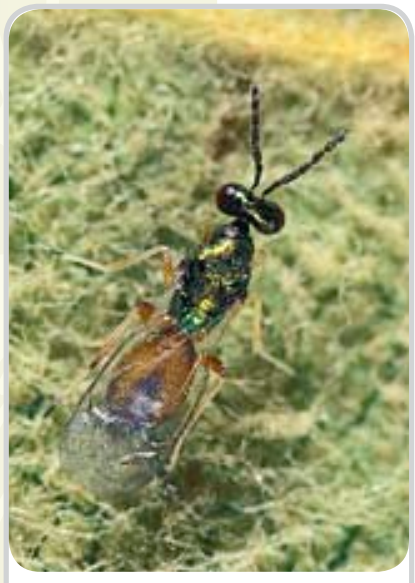

Figure 11. A Pnigalio spp. parasitoid. Photo: J. K. Clark.
CLM (LaSalle and Peňa 1997; Johnson et al. 1998; Legaspi et al. 1999). The species that dominates the native parasitoid complex varies with geographical region.

In southern California, nine species of parasitoids in five genera (Closterocerus spp., Cirrospilius spp., Pnigalio spp., Chrysocharis spp., and Sympiesis spp.; Hymenoptera: Eulophidae) have been found attacking CLM (fig. 11; J. Heraty, personal communication). These parasitoids are generalists and typically attack native gracillariid leafminers found in California. In the San Joaquin Valley, studies of the parasitoids associated with native gracillariid leafminers in oaks have detected four genera of parasitoids (Euderus spp.; Zagrammosoma spp., Sympiesis spp., and Chrysonotomyia spp; Hymenoptera: Eulophidae; Godfrey et al. 1999). It is expected that as CLM becomes more abundant in the San Joaquin Valley, additional parasitoids will attack CLM. Therefore, in managing CLM, it is important to attempt to conserve as many of these native natural enemies as possible. Around the world a number of parasitoids have been released (Ageniaspis and Citrostichus spp.) that have aided control of CLM. These parasitoids may eventually be imported into California to supplement the native natural enemies.

Parasitized CLM larvae can be recognized as the CLM larva looks dead and flattened, and often you can see the parasitoid larvae (fig. 12), prepupa (fig. 13), or pupa with meconial (fecal) pellets (fig. 14) inside the mine.

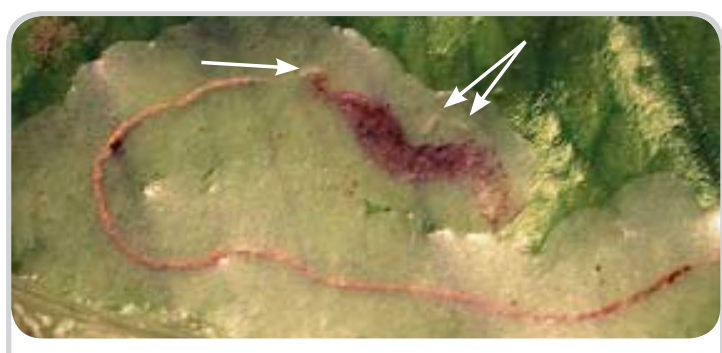

Figure 12. Parasitoid larvae (indicated by arrows) attacking a CLM larva. Photo: D. Headrick.

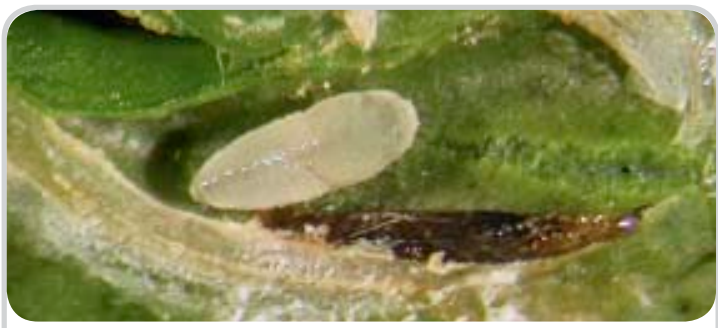

Figure 13. Prepupa of a parasitoid that has killed a CLM larva. Photo: R. Duncan, University of Florida.

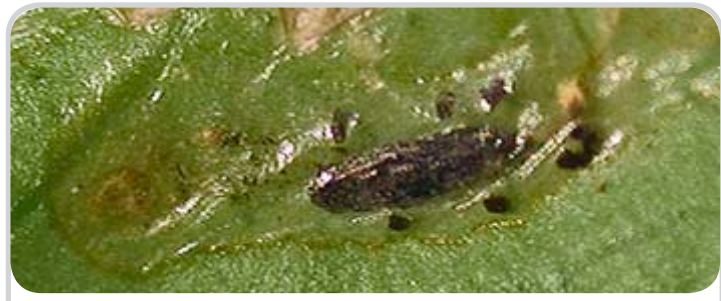

Figure 14. Pupa and meconial pellets of a parasitoid that has killed a CLM larva. Photo: D. Headrick. 


\section{CLM Management}

Research conducted in Florida has shown that CLM typically do not reduce the yield of mature trees (older than 4 years of age) provided the trees have adequate fertilizer and water at the appropriate times of the year. Chemical control of CLM in mature trees is extremely difficult, and the treatments are rarely effective. These treatments can lead to increases in the densities of other insect pests due to reduction of natural enemies. CLM can complete its life cycle in as little as 14 days and attacks only the new flush growth. During a flush period, new growth is continually being produced, so insecticide applications made at a particular time will not protect new growth that appears after the application. Young citrus trees (those less than 4 years of age) will have their growth slowed and in some cases may be killed if defoliation caused by CLM feeding is continuous. For the proper timing and use of insecticides, please refer to the UC IPM Citrus Pest Management Guidelines (http://www.ipm.ucdavis. edu/PMG/r107303211.html).

Male moths can be detected using commercially available artificial sex pheromone lures in sticky traps. The color of sticky trap is not important, but using a triangular trap with a small opening reduces the number of other insects caught in the stickem (fig. 15). CLM moths are easily identified in the traps and appear as small light brown or golden-colored moths (fig. 16) with black spots on the tips of their wings (fig. 17). The

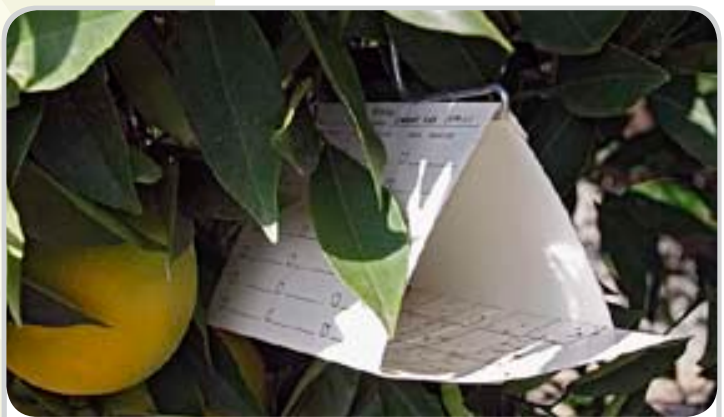

Figure 15. CLM sex pheromone attractant and sticky trap. Photo: E. Grafton-Cardwell. whitish color of the moth changes once it has been coated in the stickem. Traps should be hung at about shoulder height just inside the foliage of the citrus tree. Follow the manufacturer's recommendations

for maintaining the traps. Check the traps weekly for the presence of CLM moths, especially when the citrus trees are flushing. The traps can be used for identifying major flights. Visual inspection of leaves for CLM larvae should begin when approximately half of the trees are producing new flush growth. To find larvae, examine apical terminals (10 leaves at the end of the branch) with a hand lens for the presence of larvae. A living CLM larva moves within the mine, is pale in color, and leaves a dark- or light-colored frass trail behind it. In 1 acre of grove, two apical terminals on each of 10 trees selected at random should be inspected.

Adult CLM are attracted only to the flush growth, and therefore, proper management of tree flushes can help reduce the amount of damage caused by CLM. To help maintain a synchronized flush of short duration, avoid pruning the trees more than once per year. Do not prune CLM-damaged leaves because these leaves provide resources to the tree and pruning could cause off-cycle new flush growth that provides sites for CLM oviposition. Plan to use nitrogen fertilizers in a way that does not cause asynchrony or protracted periods of new leaf flush. Also, remove water sprouts because these shoots produce young leaf growth on which CLM can reproduce.

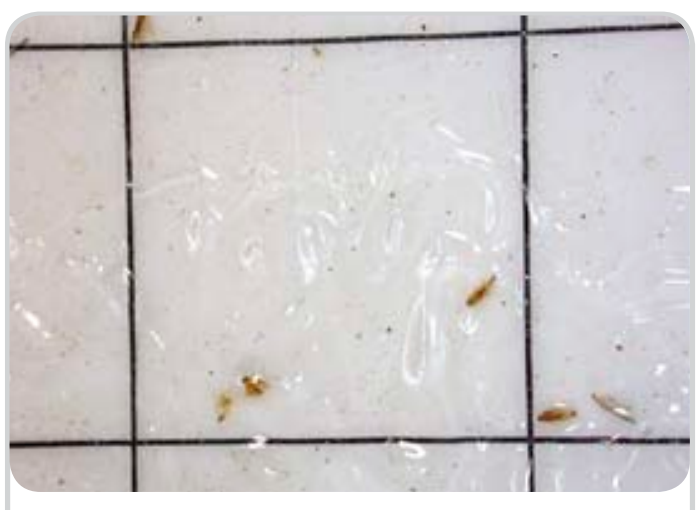

Figure 16. Male CLM trapped on a sticky card (1-inch grid). Photo: E. Grafton-Cardwell.

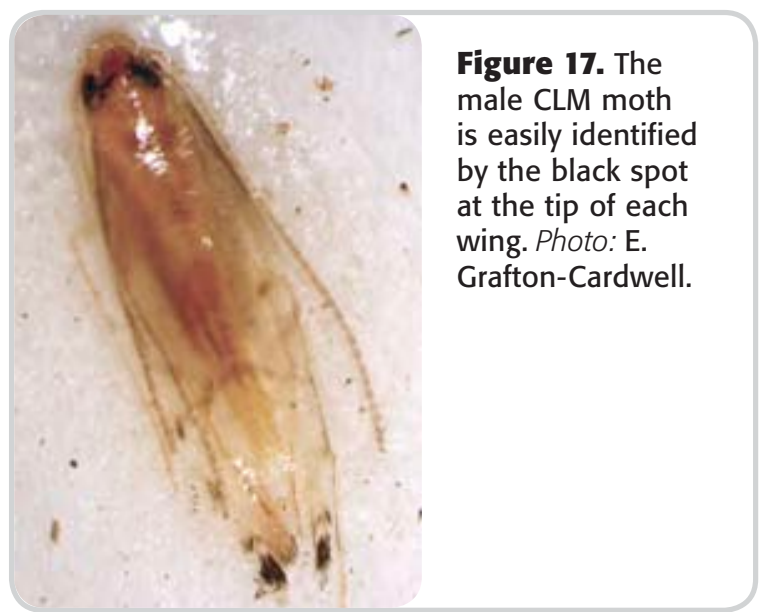




\section{CITRUS PEELMINER}

The citrus peelminer (CPM) is native to the southwestern United States and northern Mexico (Guillén et al. 2001). In California, it can currently be found in the desert valleys, the southern and central coastal areas, and in the San Joaquin Valley.

Citrus peelminer has a broad host range that includes 69 species of plants in 31 plant families. In citrus, it prefers to attack pummelos, grapefruit, and some thin-skinned varieties of oranges such as Fukumoto, Thompson Improved (TI), and Atwood navels.

The adult CPM is a small dark moth with white stripes on its body and banded legs (fig. 18). Moths are active primarily at dawn and dusk. Female moths deposit their tiny eggs singly on the surface of a stem or fruit (fig. 19), and may occasionally oviposit on a leaf. An adult female can lay an average of 49 eggs in its lifetime of approximately 11 days (Gullién et al. 2001). A small larva hatches from its egg and begins feeding just under the egg. The CPM larva creates a mine in the fruit or the stem by shearing the outermost epidermal layer. A larva (fig. 20) completes 4 to 6 instars in about 12 to 15 days at $79^{\circ} \mathrm{F}$. As a larva grows, it mines the fruit or stem, creating a mine that grows wider as the larva molts to the next instar. You can determine the instar of the larva by counting the changes in mine size (fig. 21). Just prior to pupation, a larva changes into a pink spinning form with specialized mouthparts (fig. 22). This spinning form cuts its way out of the mine, finds a suitable site for pupation, and spins a white cocoon decorated with small, white silk balls in which to pupate. The CPM pupal stage (fig. 23) lasts about 12 days at $79^{\circ} \mathrm{F}$. The time from egg to adult is approximately 29 days at $79^{\circ} \mathrm{F}$ (Gullién et al. 2001). This insect has no specific overwintering stage but continues to grow slowly during cold conditions. In the San Joaquin Valley, CPM may complete seven generations per year.

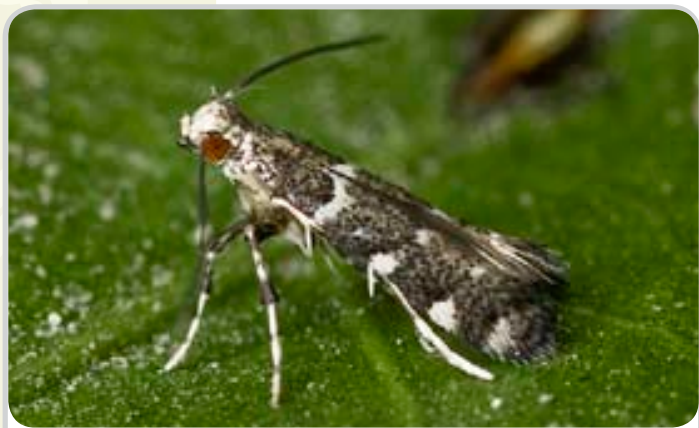

Figure 18. CPM adult moth. Photo: J. K. Clark.

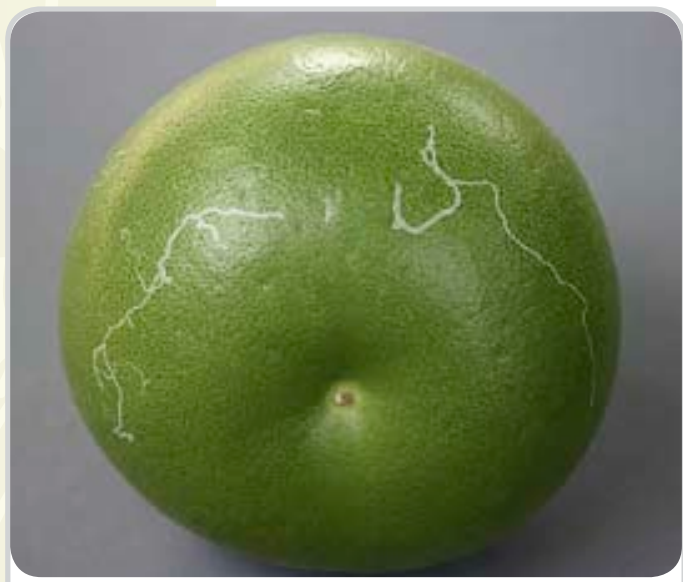

Figure 21. Early stages of CPM mining with mine size indicating first- and second-instar larva. Photo: E. Grafton-Cardwell.

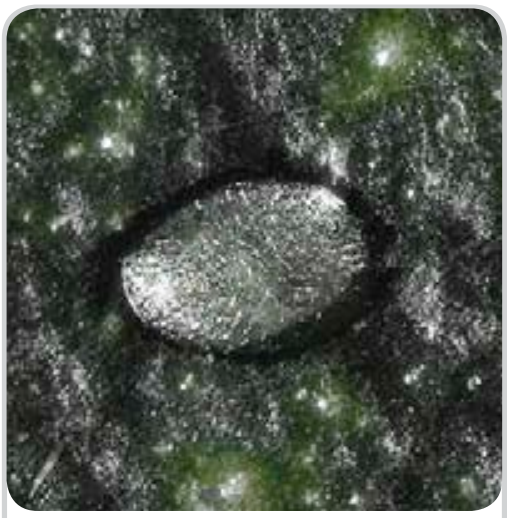

Figure 19. CPM egg on zucchini. Photo: E. Grafton-Cardwell.

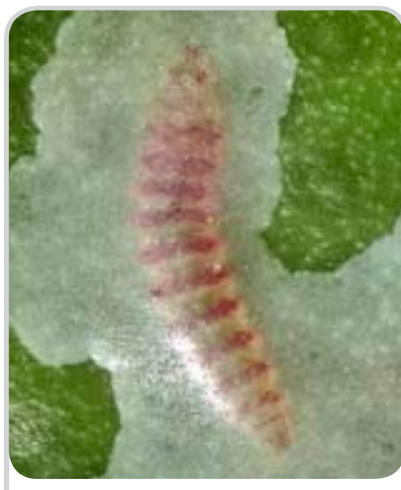

Figure 22. Spinning stage of CPM. Photo: E. GraftonCardwell.

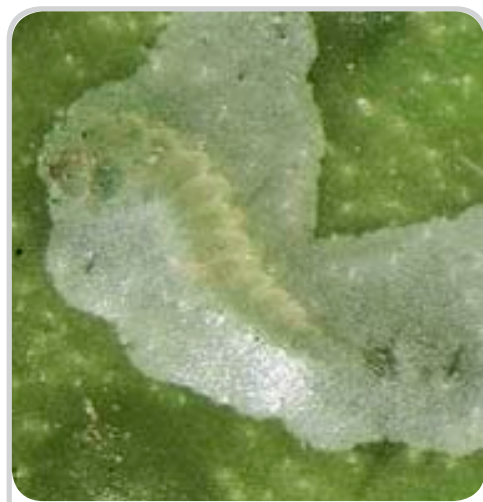

Figure 20. CPM larva mining citrus fruit. Photo: E. GraftonCardwell.

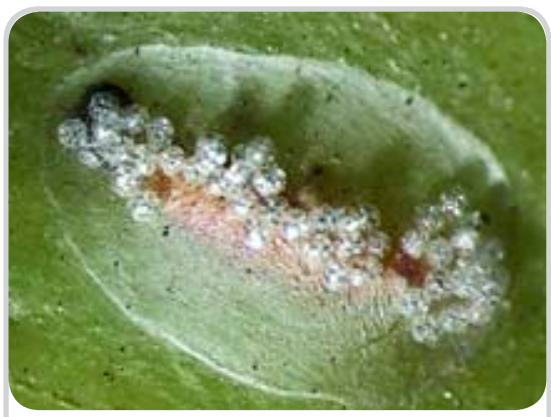

Figure 23. CPM pupa. Photo: $\mathrm{E}$. Grafton-Cardwell. 


\section{CPM Seasonal Phenology}

Its broad host range allows CPM to move from host (crops or other vegetation) to host throughout the year. In the San Joaquin Valley, CPM may reside all year in oleander and willow. In late spring, CPM begins to infest the stems of crops such as walnuts (fig. 24), grapes, plums, and weeds. In mid to late summer, densities of CPM peak in stems of dry beans, the stems and bolls of cotton (fig. 25), and the stems and fruit of grapes (fig. 26). In citrus, the fruit of pummelos and grapefruit are attacked during June and July, and susceptible navel orange varieties (i.e., Fukumoto, TI, Atwood) are attacked in the late summer and fall (fig. 27). In winter, CPM moves back to its resident hosts of oleander, willow, and citrus stems (Godfrey et al. 2003). Because of this habit of moving from crop to crop, it is difficult to manage CPM populations in citrus with insecticides. Susceptible varieties of citrus that are located next to crops that produce heavy populations of CPM (cotton and beans) are at special risk when those crops are dried for harvest in the fall months.

\section{CPM Stem and Fruit Damage}

CPM larvae mine just beneath the surface of the fruit or stem. These mines cause surface blemishes on the fruit that downgrade fruit quality for fresh market but do not harm the interior flesh of the fruit. In grapefruit, pummelos, and smoothskinned varieties of navels such as Fukumoto, TI, and Atwood, fruit damage can range from 10 to 80 percent of the fruit. In other varieties of citrus, fruit damage is usually less than 5 percent. In other crops such as cotton or grapes, the mining causes little or no economic damage to the commodity.

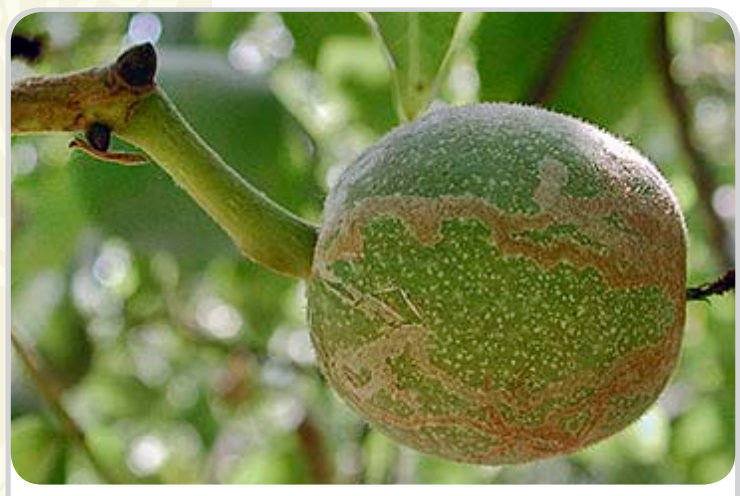

Figure 24. CPM attacking walnut stem and fruit. Photo: D. Mayhew.

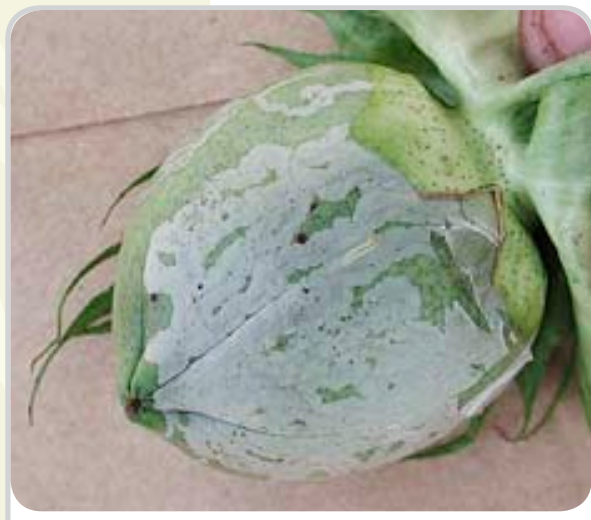

Figure 25. CPM attacking a cotton boll. Photo: D. Mayhew.

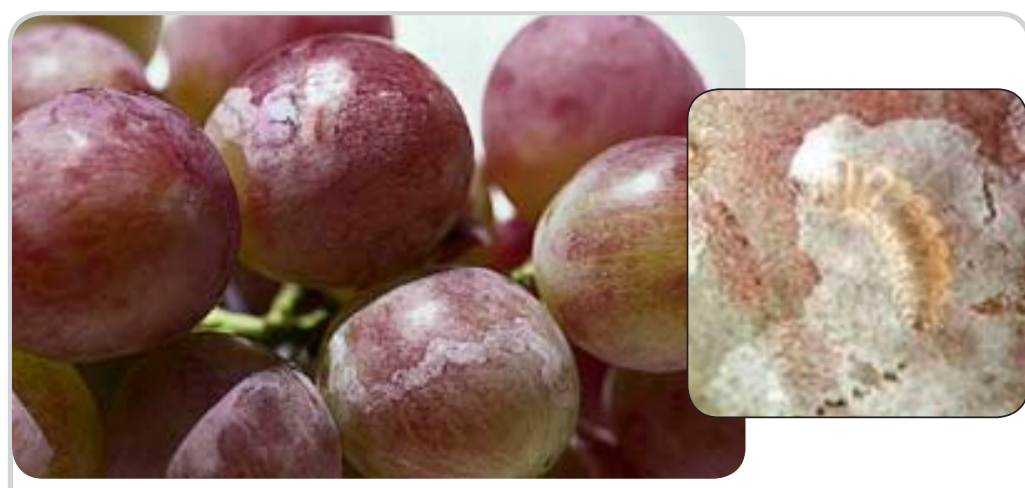

Figure 26. CPM attacking fruit of grapes. Photos: E. Grafton-Cardwell.

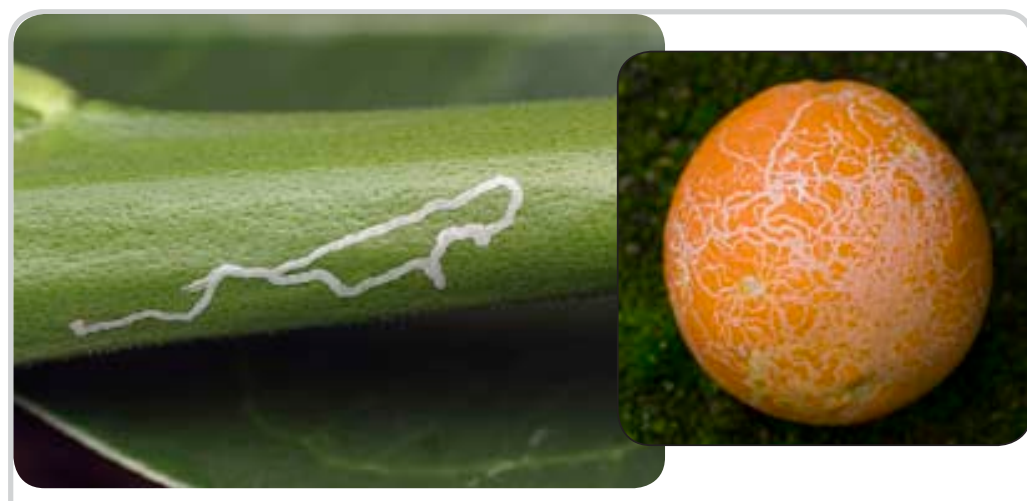

Figure 27. CPM mining citrus stem and fruit. Photos: E. Grafton-Cardwell. 


\section{CPM Biological Control}

Biological control of CPM has not been as successful as for CLM. Biological control research was initiated following the sudden increase in infestations of CPM in the San Joaquin Valley following the arrival of a new strain in 1999. A survey of

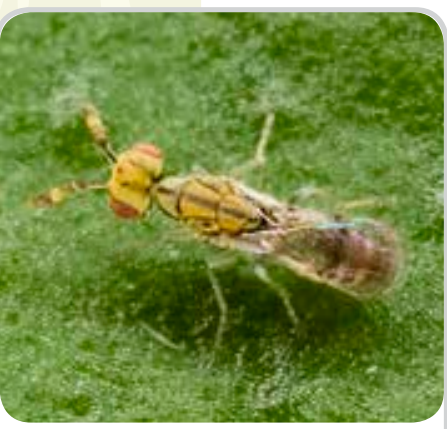

Figure 28. Cirrospilus coachellae, an important parasitoid of CPM. Photo: J. K. Clark.

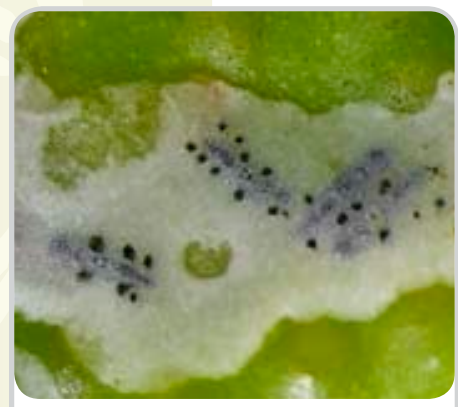

Figure 29. Exit holes and meconial pellets are evidence that Cirrospilus attacked this CPM. Photo: E. GraftonCardwell.

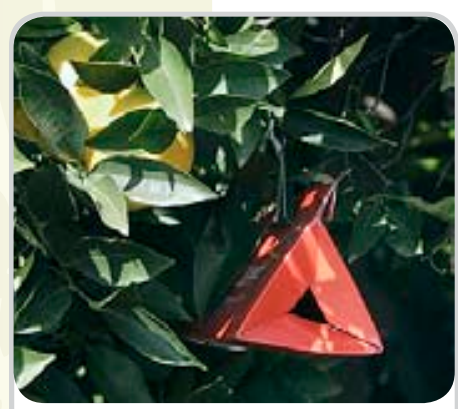

Figure 30. Pheromone trap for CPM. Photo: E. GraftonCardwell. natural enemies associated with CPM in agricultural, urban, and natural settings indicated that parasitic wasps representing five genera were parasitizing CPM larvae, albeit in extremely low numbers: Pnigalio, Closterocerus, Baryscapus, Nechrysocharoides, and Hemiptarsenus (Hymenoptera: Eulophidae). Previous research in the Coachella Valley of Southern California recorded twice as many parasitoids attacking CPM (Gates et al. 2002), and one in particular, Cirrospilus coachellae (fig. 28), was shown to provide population regulation of CPM in commercial citrus settings (Guillén et al. 2001). Since this species was absent from the San Joaquin Valley it was chosen for an introduction program that began in 2001. Releases of 10 to $200 \mathrm{C}$. coachellae per site were made during 2001-2006. Parasitism of CPM by $C$. coachellae (fig. 29) was documented in release sites where parasitoid females were caged with suitable CPM hosts on fruit. Despite these efforts, successful overwintering and establishment of $C$. coachellae in the San Joaquin Valley has not yet been documented. Surveys are underway to determine whether additional species of parasitoids from Mexico may be introduced. CPM and CLM share many of the same natural enemies, so as CLM increases its presence in the San Joaquin Valley, biological control of CPM may be improved.
In the San Joaquin Valley, two additional parasitoids have been observed attacking CPM. One species is in the genus Comperiella (Hymenoptera: Encyrtidae). The other species is Hadrotrichodes waukheon, another eulophid that is abundant on populations of CPM infesting oleander (Nerium sp.). Parasitism ranged from 6.6 to 11.2 percent; however, this species has not been observed attacking CPM since this initial observation in 2004 (C. Kirkland, personal communication).

\section{CPM Management}

Research has shown that male moths can be collected using artificial sex pheromone lures in sticky traps (fig. 30). Trap shape is triangular, with as small an opening as possible to prevent other insects from entering. Traps are hung at shoulder height just inside the foliage of the citrus tree. Trap color is not important, but having a trap color that is different for CLM and CPM traps helps avoid confusion. CPM moths are easily identified as small dark moths with banded legs (fig. 31).

Because the CPM synthetic pheromone (not yet commercially available) is only weakly attractive to $\mathrm{CPM}$, traps are effective only in detecting the initiation of the first male flight. However, the initial biofix may be used to predict the initial infestation of each citrus group and so can aid the timing of insecticide treatments. CPM has a lower developmental threshold LDt of $55^{\circ}$ F. Starting with the biofix date of first male flight or first appearance of larvae in noncitrus host plants such as stems of willows or walnuts, a generation

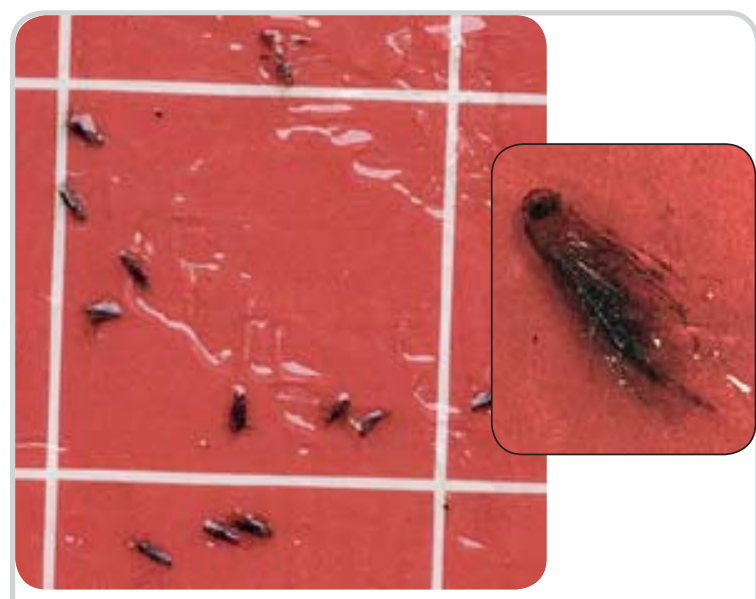

Figure 31. CPM male moth on a sticky card showing banding of legs and white stripes on wings (1-inch grid). Photo: E. Grafton-Cardwell. 


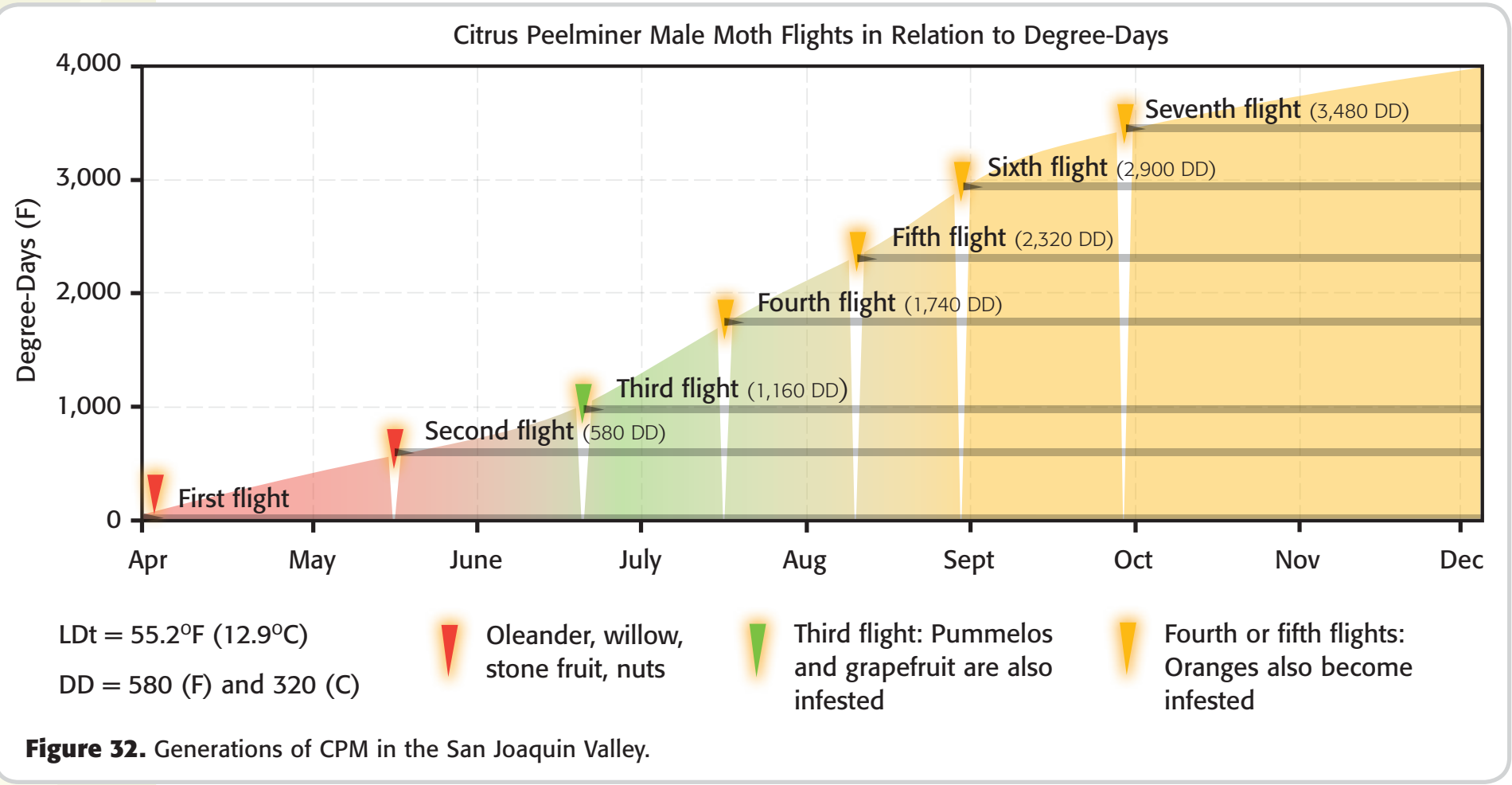

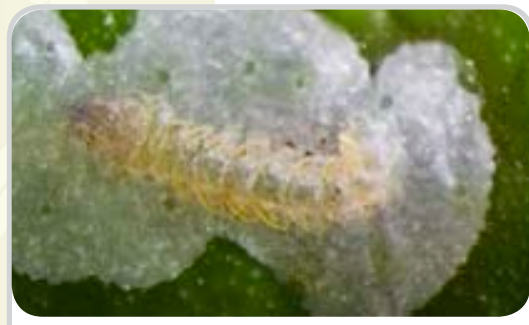

Figure 33. Healthy, yellow, plump CPM larva. Photo: E. Grafton-Cardwell.

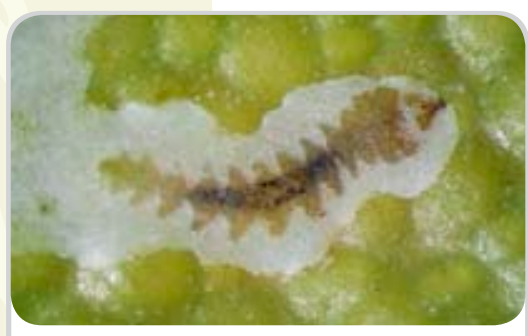

Figure 34. Dead, brown, flattened CPM larva. Photo: E. Grafton-Cardwell.

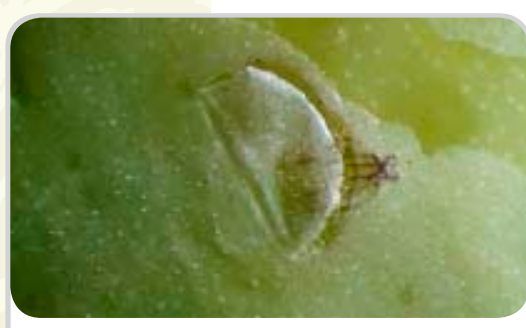

Figure 35. CPM emerged from a hole in the mine. Photo: E. GraftonCardwell. of CPM is completed every 580 (Fahrenheit) degree days (DD) (fig. 32). The first two flights of CPM attack stems of noncitrus host plants. The adults in the third flight deposit eggs on pummelo and grapefruit. In the fourth or fifth flight, moths continue to attack grapefruit and pummelo and begin to deposit eggs on susceptible navel orange varieties. Citrus peelminer requires a minimum fruit diameter of about 3 inches for grapefruit and pummelos and about 2.5 inches for navels for successful larval development (S. Finch and D. Headrick, unpublished data).

Management of CPM with insecticides is difficult because female moths prefer to deposit eggs on fruit in the lower inside canopy and it is difficult to cover this area adequately with a foliar spray application. Additionally, larvae are protected inside their mines from contact poisons. The recommendation for less-susceptible varieties of citrus is to avoid spraying since damage is usually less than 5 percent of fruit mined. For susceptible varieties of citrus (pummelo, grapefruit, Atwood, Fukumoto, $\mathrm{TI}$ ), insecticide treatments applied at the initiation of each of the first three flights attacking the crop are recommended, especially if the citrus is located next to a crop such as cotton or beans that supports heavy populations of CPM. For the proper timing and use of insecticides, please refer to the UC IPM Citrus Pest Management Guidelines (http://www.ipm.ucdavis.edu/PMG/selectnewpest.citrus.html).

\section{Monitoring for Damage}

Visual inspection of citrus fruit should take place weekly when a damaging flight is predicted to occur. In each quadrant of the block, examine fruit for mining activity, especially fruit that is low and on the inside of the tree. A live CPM larva moves within the mine and is pale in color (fig. 33). A dead CPM is motionless and darkened (fig. 34). An emerged larva leaves behind its head capsule and flattened skin, and the mine will have a hole in it (fig. 35). Take note of the stages (young larvae make narrow mines; older larvae make wide mines) of live, healthy CPM larvae in a 250-fruit sample in each of four quadrants of the orchard. Insecticide treatments should be timed for expected flights of moths, or the first appearance of larvae. 


\section{Differentiating Between Citrus Leafminer and Citrus Peelminer}

Citrus leafminer and citrus peelminer can occur on the same tree. While leafminer rarely attacks fruit and peelminer rarely attacks leaves, some crossover can occur. Table 1 is a guide to differentiating which species is in an orchard. Because artificial sex pheromone lures are unique to each species of moth, pheromone traps could also be used to determine which species are present.

Table 1. Distinguishing citrus leafminer and citrus peelminer

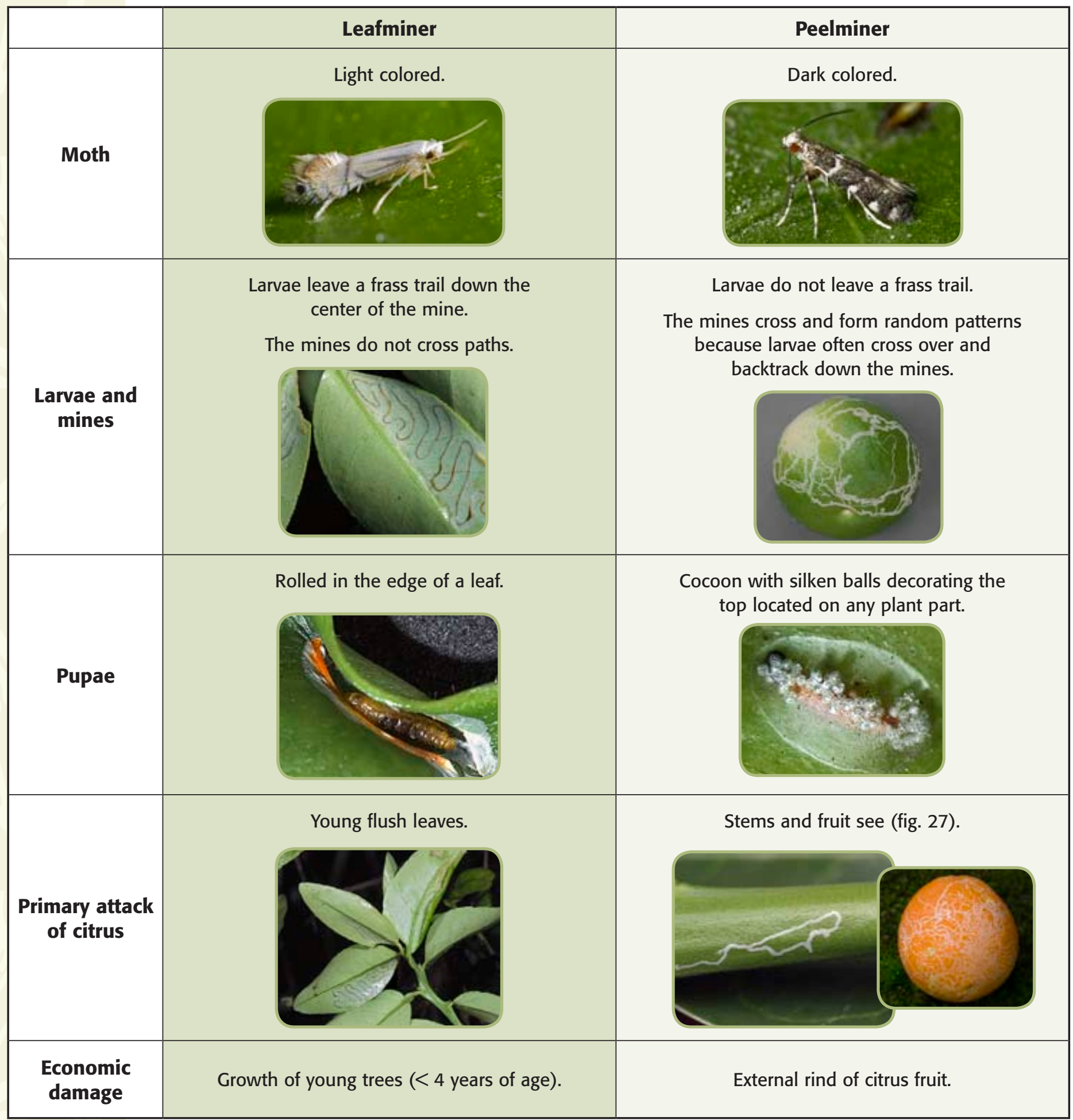




\section{References}

Amalin, D. M., J. E. Peňa, R. E. Duncan, H. W. Browning, and R. McSorley. 2002. Natural mortality factors acting on citrus leafminer, Phyllocnistis citrella, in lime orchards in South Florida. BioControl 47:327-347.

Ba-Angood, S. A. S. 1978. On the biology and food preference of the citrus leafminer, Phyllocnistis citrella Stainton (Gracillariidae), in PDR of Yemen. Zeitschrift für Angewandte Entomologie 86:53-57.

Belasque, J. Jr., A. L. Parra-Pedrazzoli, J. R. Neto, P. T. Yamamoto, M. C. M. Chagas, J. R. P. Parra, B. T. Vinyard, and J. S. Hartung. 2005. Adult citrus leafminers (Phyllocnistis citrella) are not efficient vectors for Xanthamonas axonopodis pv. citri. Plant Disease 89:590-594.

Bermudez, E. C., N. B. Martinez, J. V. Graziano, H. C. A. Bernal, and A. H. Paniagua. 2004. Phyllocnistis citrella (Lepidoptera: Gracillariidae) and its parasitoids in citrus in Ecuador. Florida Entomologist 87:10-17. http://www.fcla.edu/FlaEnt/fe87p10.pdf.

Clausen, C. P. 1931. Two citrus leaf miners of the Far East. USDA Technical Bulletin No. 252: 1-13.

Gates, M. W., J. M. Heraty, M. E. Schauff, D. L. Wagner, J. B. Whitfield, and D. B. Wahl. 2002. Survey of the parasitic Hymenoptera on leafminers in California. Journal of Hymenoptera Research 11:213-270.

Godfrey, K., J. Heraty, N. Smith, and D. Haines. 1999. Multi-year survey of parasites of native Gracillariidae: A possible source of parasites for the citrus leafminer. In D. Woods, ed., Biological Control Program annual summary 1998. Sacramento: California Department of Food and Agriculture. 43-44.

Godfrey, K., D. A. Mayhew, K. Daane, and D. Haines. 2003. Seasonal dynamics of the citrus peelminer in Tulare County. In D. Woods, ed., Biological Control Program annual summary 2002. Sacramento: California Department of Food and Agriculture. 29-32. http://www.cdfa.ca.gov/phpps/ipc/biocontrol/ pdf/annualreports/2002bc_annualreport.pdf.

Gottwald, T. R., X. Sun, T. Riley, J. H. Graham, F. Ferrandino, and E. L. Taylor. 2002. Geo-referenced spatiotemporal analysis of the urban citrus canker epidemic in Florida. Phytopathology 92:362-377.

Guillén, M., D. R. Davis, and J. M. Heraty. 2001. Systematics and biology of a new polyphagous species of Marmara (Lepidoptera: Gracillariidae) infesting grapefruit in the southwestern United States. Proceedings of the Entomological Society of Washington 103:636-654.

Heppner, J. B. 1993. Citrus leafminer, Phyllocnistis citrella, in Florida (Lepidoptera: Gracillariidae: Phyllocnistinae). Tropical Lepidoptera 4:49-64.

- 1995. Citrus leafminer (Lepidoptera: Gracillariidae) on fruit in Florida. Florida Entomologist 78:183-186. http://www.fcla.edu/FlaEnt/fe78p183.pdf.

Hoy, M. A., and C. Jessey. 2004. Ageniaspis citricola (Hymenoptera: Encyrtidae) established in Bermuda. Florida Entomologist 87:229-230. http://www.fcla.edu/FlaEnt/fe87p229.pdf.

Johnson, S., A. Vaughn, and W. Bourgeois. 1998. Biological control of the citrus leafminer in Louisiana. Louisiana Agriculture 41:11-14.

LaSalle, J., and J. E. Peña. 1997. A new species of Galeopsomyia (Hymenoptera: Eulophidae: Tetrastichinae): A fortuitous parasitoid of the citrus leafminer, Phyllocnistis citrella (Lepidoptera: Gracillariidae). Florida Entomologist 80:461-470. http://www.fcla.edu/FlaEnt/fe80p461.pdf.

Legaspi, J. C., J. V. French, M. E. Schauff, and J. B. Woolley. 1999. The citrus leafminer Phyllocnistis citrella (Lepidoptera: Gracillariidae) in South Texas: Incidence and parasitism. Florida Entomologist 82:305-316. http://www.fcla.edu/FlaEnt/fe82p305.pdf.

Lim, U. T., and M. A. Hoy. 2006. Overwintering of the citrus leafminer, Phyllocnistis citrella (Lepidoptera: Gracillariidae), without diapause in Florida. Florida Entomologist 89:361-366. http://www.fcla.edu/ FlaEnt/fe89p361.pdf.

Murai, M. 1974. Studies on the interference among larvae of the citrus leafminer, Phyllocnistis citrella Stainton (Lepidoptera: Phyllocnistidae). Researches on Population Ecology 16:80-111.

Peña, J. E., R. Duncan, and H. Browning. 1996. Seasonal abundance of Phyllocnistis citrella (Lepidoptera: Gracillariidae) and its parasitoids in south Florida citrus. Environmental Entomology 25:698-702. 
Polek, M., G. Vidalakis, and K. Godfrey. 2007. Citrus bacterial canker disease and huanglongbing (citrus greening). Oakland: UC ANR Publication 8218. http://anrcatalog.ucdavis.edu/pdf/8218.pdf.

Rogers, M. E., and P. A. Stansly. 2007. 2007 Florida citrus pest management guidelines: Asian citrus psyllid and citrus leafminer. Florida Cooperative Extension Service, Institute of Food and Agricultural Sciences, University of Florida. ENY-734. http://edis.ifas.ufl.edu/IN686.

Ruiz-Cancino, E., and J. M. Coronado Blanco. 1994. Minador de la hoja de los citricos Phyllocnistis citrella Stainton (Lepidoptera: Gracillariidae: Phyllocnistinae). Centro de Investigaciones, Facultad de Agronomía, Universidad Autónoma de Tamaulipas 1:1-2.

Schubert, T., S. and X. Sun. 2003. Bacterial citrus canker. Florida Department of Agriculture Conservation Service, Division of Plant Industry Plant Pathology Circular No. 377. http://www.doacs.state.fl.us/pi/ enpp/pathology/pathcirc/ppcirc377-rev5.pdf.

Wilson, C. G. 1991. Notes on Phyllocnistis citrella Stainton (Lepidoptera: Phyllocnistidae) attacking four citrus varieties in Darwin. Journal of the Australian Entomological Society 30:77-78.

\section{Metric-English Conversions}

\begin{tabular}{|c|c|c|c|}
\hline English & $\begin{array}{c}\text { Conversion factor for } \\
\text { English to Metric }\end{array}$ & $\begin{array}{c}\text { Conversion factor for } \\
\text { Metric to English }\end{array}$ & Metric \\
\hline inch (in) & 25.4 & 0.0394 & millimeter $(\mathrm{mm})$ \\
\hline Fahrenheit $\left({ }^{\circ} \mathrm{F}\right)$ & ${ }^{\circ} \mathrm{C}=\left({ }^{\circ} \mathrm{F}-32\right) \div 1.8$ & ${ }^{\circ} \mathrm{F}=\left({ }^{\circ} \mathrm{C} \times 1.8\right)+32$ & Celsius $\left({ }^{\circ} \mathrm{C}\right) *$ \\
\hline
\end{tabular}

${ }^{*}$ This conversion is for temperatures only, not for use with degree-days. For conversion from Fahrenheit to Celsius degree days, see the UC IPM Web site, http://www.ipm.ucdavis.edu/WEATHER/ddretrieve.html.

\section{For Further Information}

To order or obtain ANR publications and other products, visit the ANR Communication Services online catalog at http://anrcatalog. ucdavis.edu or phone 1-800-994-8849. You can also place orders by mail or FAX, or request a printed catalog of our products from

\section{University of California}

Agriculture and Natural Resources

Communication Services

6701 San Pablo Avenue, 2nd Floor

Oakland, California 94608-1239

Telephone 1-800-994-8849

(510) 642-2431

FAX (510) 643-5470

E-mail: danrcs@ucdavis.edu

Publication 8321

ISBN-13: 978-1-60107-565-9

Photo credits are given in the captions.

(C)2008 The Regents of the University of California Division of Agriculture and Natural Resources All rights reserved.

No part of this publication may be reproduced, stored in a retrieval system, or transmitted, in any form or by any means, electronic, mechanical, photocopying, recording, or otherwise, without the written permission of the publisher and the authors.
The University of California prohibits discrimination or harassment of any person on the basis of race, color, national origin, religion, sex, gender identity, pregnancy (including childbirth, and medical conditions related to pregnancy or childbirth), physical or mental disability, medical condition (cancer-related or genetic characteristics), ancestry, marital status, age, sexual orientation, citizenship, or status as a covered veteran (covered veterans are special disabled veterans, recently separated veterans, Vietnam era veterans, or any other veterans who served on active duty during a war or in a campaign or expedition for which a campaign badge has been authorized) in any of its programs or activities. University policy is intended to be consistent with the provisions of applicable State and Federal laws.

Inquiries regarding the University's nondiscrimination policies may be directed to the Affirmative Action/Staff Personnel Services Director, University of California, Agriculture and Natural Resources, 1111 Franklin Street, $6^{\text {th }}$ Floor, Oakland, CA 94607-5201, (510) 987-0096. For information about ordering this publication, telephone 1-800-994-8849.

To simplify information, trade names of products have been used. No endorsement of named or illustrated products is intended, nor is criticism implied of similar products that are not mentioned or illustrated.

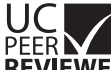

REVIEWED This publication has been anonymously peer reviewed for technical accuracy by University of California scientists and other qualified professionals. This review process was managed by the ANR Associate Editor for Pest Management. 